\title{
Diabetes mellitus: Implication in rural area of Thane district, India
}

\author{
Seema Sanjay Bansode-Gokhe, Rakesh Balaji Waghmare ${ }^{1}$, Ratnerdra Shinde Ratnendra \\ Department of Community Medicine, Seth G. S. Medical College, Mumbai, '1Shri V.N. Government Medical College, Yavatmal, Maharashtra, India
}

\section{A B S T R A C T}

Context: Diabetes mellitus along with its complications contribute a significant amount of burden on the society. Lack of awareness has resulted in an increased number of diabetics over the years. Aims: To study the sociodemographic status, complication profile and perception of diabetic patients regarding their illness. Settings and Design: Cross sectional center based study done on 110 type 2 diabetic patients over a period of 5 months at rural health training center. Materials and Methods: Universal sampling technique was used.All old and newly diagnosed diabetic patients were interviewed by Face to Face interview method. Statistical Analysis: Descriptive statistics for sociodemographic factors and morbidity; cross tabulation by using test of significance to find association between different variables were used. Results: $50 \%$ patients were illiterate, $91.82 \%$ were married and $44.5 \%$ were farmers. The perception of self-health was reported "GOOD" on Stanford patient education research center questionnaire scale in $62.7 \%$ patients; these responses were significantly associated with males. $61.81 \%$ patient had symptoms of coronary heart disease (CHD). $87.3 \%, 59.1 \%$, and $58.2 \%$ patient had symptoms of neuropathy, nephropathy and retinopathy respectively. Out of $6 \mathrm{I}$ patients who were aware of complications only I/I $0^{\text {th }}$ were aware with the fact that diabetes can affect eye and heart. Conclusions: Almost half patients were unaware that disease is associated with complications and in remaining halves awareness was negligible for neuropathy and nephropathy. In contrast around $2 / 3^{\text {rd }}$ patients had symptoms of CHD, nephropathy and retinopathy.

Key words: Complications, diabetes mellitus, perception, rural

\section{INTRODUCTION}

The International Diabetes Federation estimated about $6 \%$ adults having diabetes. ${ }^{[1]}$ Indian Council of Medical Research in 1970 reported a prevalence of $1 \%$ in rural areas which had increased to $3-10 \%$ in 2010 and in the other study it was reported to be $13.2 \%{ }^{[2-4]} 25 \%$ are believed to have retinopathy, $9 \%$ neuropathy and $8 \%$ nephropathy at the time of diagnosis. ${ }^{[5]}$ Diabetes is responsible for approximately $12 \%$ of blindness and $24 \%$ increased risk of developing depression. ${ }^{[6,7]}$ This study had focused on the

\begin{tabular}{|l|l|}
\hline \multicolumn{2}{|c|}{ Access this article online } \\
\hline Quick Response Code: & Website: \\
\hline & www.joshd.net \\
\hline & \\
\hline & \\
\hline
\end{tabular}

prevalence of complications and level of disease awareness. The objectives were to study the sociodemographic status, complications and patient's perception for illness.

\section{MATeRIALS ANd Methods}

It was a cross sectional study done over the duration of 5 months From December 2011 to April 2012. Study was carried out in rural health training center of Seth GS Medical College Mumbai situated in Sakwar village of Thane district. Total 119 known type 2 diabetic patients were enrolled for the study. Out of this 119 patients some were registered to the rural health training center for their treatment and follow-up and remaining were those patients who had diagnosed diabetes mellitus during screening (symptoms with casual plasma glucose $\geq 200 \mathrm{mg} / \mathrm{dl}$ confirmed on a subsequent day by fasting plasma glucose $\geq 126 \mathrm{mg} / \mathrm{dl}$ ). Universal sampling technique method was applied for selection of patients in which all old and newly diagnosed diabetic patients

Corresponding Author: Dr. Rakesh Balaji Waghmare, Quarter Number 01, Type 3 Quarter, SVN GMC, Yavatmal - 445 001, Maharashtra, India. E-mail: rakeshbw0326@gmail.com 
attending the health center during January to March 2012 were enrolled in the study.

In the preparatory phase written permission from the head of the department and head of the rural training center was taken, and then the questionnaire regarding perception and awareness were taken from sample questionnaire of Stanford patient education research center. ${ }^{[8]}$ Semi-structured proforma was prepared according to the objectives of the study and pilot study was conducted on 10 study subjects. Five patients had symptoms of coronary heart disease (CHD). 7, 7 and 5 patient had symptoms of neuropathy, nephropathy and retinopathy respectively. Only 4 patients were aware of complications. Then the proforma was restructured accordingly after the analysis of pilot study data.

In observational phase, all known diabetic patients and those patients who were identified as diabetic during screening were firstly treated for their presenting ailments and after giving detail study information and obtaining written consent were enrolled for the study, then each patient was interviewed by Face to Face interview method after taking informed consent of participants and confidentiality was maintained, and the data was collected with the help of a structured questionnaire. Symptoms of complication were further confirmed by necessary referral.

Data was entered in Microsoft excel software 2007 version, and statistical analysis was done by using SPSS version 18 software. For sociodemographic factors and morbidity, descriptive statistics was done. Cross tabulation was made to find an association between different variables and then Chi-square test, $t$-test was applied wherever applicable.

\section{RESULTS}

Out of 119 patients, 110 (92.43\%) patients had given consent for participation.

Among the respondent $48(43.6 \%)$ were male and 62 $(56.4 \%)$ were female. Most of the patients $73.6 \%$ that is, 81 was between the age group of $46-60$ years. The mean age of male patients was 54.2 years with 4.198 standard deviation, and that of the female patient was 54.84 years with 11.903 standard deviation. $50 \%$ patients were illiterate, and only $14(12.7 \%)$ could study beyond $4^{\text {th }}$ standard. $91.82 \%$ (101) respondent were married, and remaining 9 patients were single because of the death of spouse or divorce about half, that is, $44.5 \%$ patients were farmer by occupation. The disease was more commonly found in age group of
46-60 years and it was statistically significantly associated with males in that age group [Table 1].

The perception of self-general health was reported "GOOD" on Stanford patient education research center questionnaire scale in $62.7 \%(69)$ patients. $6.4 \%$ (7) responded with "VERY GOOD" perception response, and none of the patient responded with "EXCELLENT" and "POOR" response. After applying Pearson Chi-square test, these responses were significantly associated with male gender $(P=0.000)$. On asking were they discouraged by their health problem in the past month, 36.4\% (40) patients responded with "LITTLE OF THE TIME" response, whereas 25.5\% (28) and $12.7 \%$ (14) patients were reported with "A GOOD BIT OF THE TIME" and "MOST OF THE TIME" response respectively. The responses were significantly associated with male patients after applying Pearson Chi-square test $(P=0.014)$. Similar findings were obtained for fearful future health, frustration from disease [Table 2].

The median for fatigue, breathlessness and pain on Stanford patient education research center questionnaire scale which has 0-10 marking ranging from no symptom to severe suffering was 4, 5 and 4 respectively, and the mode was for these symptoms was 3, 2 and 6 respectively. The mean rank for fatigue in male was 40.49 and for female was 67.12, on applying Mann - Whitney U-test this difference was highly significant with $P=0.000$. Statistical significant difference was also found for pain symptom $(P=0.016)$ but not found for breathlessness. This showed the fatigue and pain was significantly higher in females [Table 3].

$61.81 \%$ patient had symptoms suggestive of CHD in the form of breathlessness, paroxysmal nocturnal dyspnea,

\begin{tabular}{|c|c|c|c|c|}
\hline Characteristic & $\begin{array}{c}\text { Male } \\
(n=48)\end{array}$ & $\begin{array}{l}\text { Female } \\
(n=62)\end{array}$ & $\begin{array}{c}\text { Total } \\
(n=110)\end{array}$ & $\boldsymbol{P}$ \\
\hline \multicolumn{5}{|l|}{ Age } \\
\hline$\leq 45$ & 0 & 15 & 0 & 0.001 \\
\hline $46-60$ & 48 & 33 & 48 & \\
\hline$\geq 61$ & 0 & 14 & 0 & \\
\hline \multicolumn{5}{|l|}{ Literacy } \\
\hline Illiterate & 15 & 40 & 55 & 0.001 \\
\hline Till primary ( $4^{\text {th }}$ std.) & 23 & 18 & 41 & \\
\hline Beyond primary & 10 & 4 & 14 & \\
\hline \multicolumn{5}{|l|}{ Marital status } \\
\hline Married & 47 & 54 & 101 & $0.0393^{*}$ \\
\hline Unmarried & 0 & 0 & 0 & \\
\hline Widow/widower/divorcee & 1 & 8 & 9 & \\
\hline \multicolumn{5}{|l|}{ Occupation } \\
\hline Farmer & 20 & 29 & 49 & 0.000 \\
\hline Unemployed & 10 & 30 & 40 & \\
\hline Service & 18 & 03 & 21 & \\
\hline
\end{tabular}

${ }^{*}$ Fisher exact tests 


\begin{tabular}{|c|c|c|c|c|c|c|}
\hline \multirow{2}{*}{$\begin{array}{l}\text { Parameters of Stanford patient education } \\
\text { research centre questionnaire }\end{array}$} & \multirow[t]{2}{*}{ Responses } & \multicolumn{2}{|c|}{ Gender } & \multirow{2}{*}{$\begin{array}{l}\text { Pearson Chi-square } \\
\text { value }\end{array}$} & \multirow[t]{2}{*}{ df } & \multirow[t]{2}{*}{$P$} \\
\hline & & Male & Female & & & \\
\hline \multirow[t]{3}{*}{ Perception regarding general health } & Very good & 7 & 0 & 17.277 & 2 & 0.0001 \\
\hline & Good & 34 & 35 & & & \\
\hline & Fair & 7 & 27 & & & \\
\hline \multirow[t]{5}{*}{ Discourage by health problem } & None of the time & 7 & 7 & 12.419 & 4 & 0.014 \\
\hline & Little of the time & 20 & 20 & & & \\
\hline & Some of the time & 7 & 7 & & & \\
\hline & A good bit of the time & 14 & 14 & & & \\
\hline & Most of the time & 0 & 14 & & & \\
\hline \multirow[t]{5}{*}{ Fearful future due to disease } & None of the time & 21 & 7 & 32.767 & 4 & 0.0001 \\
\hline & Little of the time & 27 & 28 & & & \\
\hline & Some of the time & 0 & 14 & & & \\
\hline & A good bit of the time & 0 & 6 & & & \\
\hline & Most of the time & 0 & 7 & & & \\
\hline \multirow[t]{5}{*}{ Worried in your life due to disease } & None of the time & 21 & 14 & 19.960 & 4 & 0.001 \\
\hline & Little of the time & 27 & 28 & & & \\
\hline & Some of the time & 0 & 7 & & & \\
\hline & A good bit of the time & 0 & 6 & & & \\
\hline & Most of the time & 0 & 7 & & & \\
\hline
\end{tabular}

\begin{tabular}{|c|c|c|c|c|}
\hline \multicolumn{5}{|c|}{$\begin{array}{l}\text { Table 3: Comparison of symptoms in male and female } \\
\text { study patients }\end{array}$} \\
\hline \multirow[t]{2}{*}{ Symptoms } & \multirow[t]{2}{*}{ Gender } & \multicolumn{3}{|c|}{ Ranks } \\
\hline & & $\begin{array}{l}\text { Mean } \\
\text { rank }\end{array}$ & $\begin{array}{l}\text { Mann-Whitney } \\
\text { U-test }\end{array}$ & Significance \\
\hline \multirow[t]{2}{*}{ Fatigue } & Male & 40.49 & 767.500 & 0.0001 \\
\hline & Female & 67.12 & & \\
\hline \multirow[t]{2}{*}{ Pain } & Male & 47.27 & 109.3 & 0.016 \\
\hline & Female & 61.87 & & \\
\hline Breathlessness & Male & 50.84 & 1264.5 & 0.172 \\
\hline
\end{tabular}

swelling over feet, etc. $87.3 \%$ patient had symptoms suggestive of neuropathy like tingling and numbness in lower limbs, impaired fine coordination. 59.1\% patients had a history of passing foamy urine suggestive of diabetic nephropathy, and $58.2 \%$ patients had history suggestive of retinopathy respectively. None of the patient reported with nonhealing ulcer.

However, in contrast only 55.5\% (61) patients were aware with the fact that the Diabetes is associated with complications. And out of 61 patients who were aware of complications all were aware about nonhealing ulcer and only about $1 / 10^{\text {th }}$ patients were aware of the fact that diabetes can affect heart and eyes. Awareness was negligible for nephropathy and neuropathy [Figure 1].

\section{DISCUSSION}

The higher prevalence of complication is obtained in this study as compared to the finding of the study conducted by Vaz et al. in rural Goa, India in 2011, they had found $32.3 \%$ CHD, $60 \%$ neuropathy and $15.4 \%$ Retinopathy. ${ }^{[0]}$ In another study conducted by Ramachandran et al. in

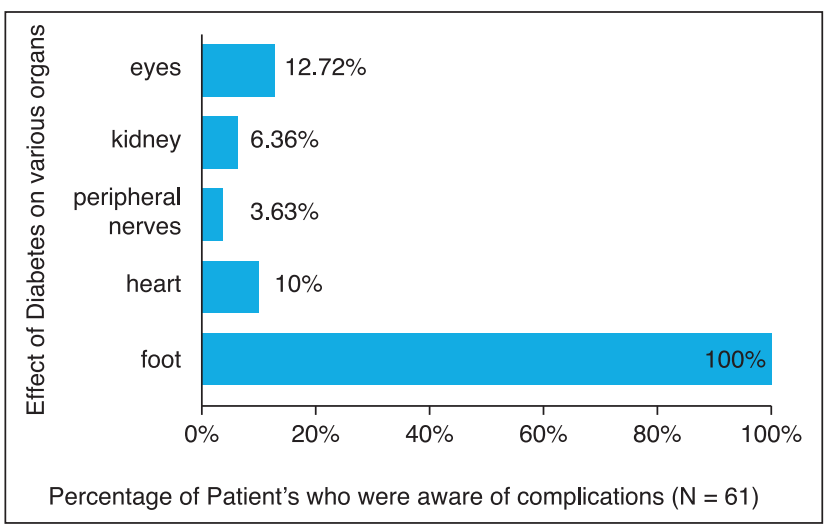

Figure 1: Patients knowledge regarding the effect of diabetes on various organs

Chennai, India in 1999 they had found 11.4\% CHD, 27.5\% Neuropathy and 23.7\% Retinopathy, these findings are also in contrast with the current study. ${ }^{[10]}$ According to National Diabetes statistics, 2011 the prevalence of complication in united state was $68 \%$ CHD, $60-70 \%$ neuropathy, $44 \%$ nephropathy and $28.5 \%$ retinopathy ${ }^{[1]]}$ [Table 4].

As India is a developing country, but according to census 2011 still $>2 / 3^{\text {rd }}$ population still living in rural India. As a rising trend of Non Communicable Diseases in urban, as well as rural India, it is responsible for early mortality and causes huge economical burden for patients and nation.

Diabetes is known as "Silent killer." Early detection, regular treatment and self-care improve the outcome of the disease. It is found in the study that only $55.5 \%$ patients were aware with the Diabetes complications and in contrast there were $61.81 \%$ and $87.3 \%$ patient had 


\begin{tabular}{lcccc}
\hline Table 4: Comparison of prevalence of complication with other studies & & \\
\hline Complication & $\begin{array}{c}\text { Study findings (\%) } \\
(\boldsymbol{n}=\mathbf{1 1 0})\end{array}$ & $\begin{array}{c}\text { Nafisa et al., rural Goa, } \\
\mathbf{2 0 1 1}(\%)\end{array}$ & $\begin{array}{c}\text { Ramachandran et al, } \\
\text { Chennai, 1999 (\%) }\end{array}$ & $\begin{array}{c}\text { National diabetes } \\
\text { statistics, US 2011 (\%) }\end{array}$ \\
\hline Coronary heart disease & $61.81(n=68)$ & 32.3 & 11.4 & 68 \\
Retinopathy & $58.2(n=64)$ & 15.4 & 23.7 & 28.5 \\
Nephropathy & $59.1(n=65)$ & - & - & 44 \\
Neuropathy & $87.3(n=96)$ & 60 & 27.5 & $60-70$ \\
\hline
\end{tabular}

symptoms suggestive of CHD and neuropathy respectively. Furthermore, $59.1 \%$ and $58.2 \%$ patients had history suggestive of diabetic nephropathy and retinopathy respectively.

Patient education regarding self-care and knowledge regarding disease should be incorporated in treatment. As the treatment card was available with each patient, symptoms suggestive of complications should be mentioned in regional, local language and patient should be taught to mark on the corresponding symptom, and it should be informed in next visit to the doctor. Almost $2 / 3^{\text {rd }}$ patient has symptoms of CHD and which is the leading cause of death in diabetes, so the regular follow-up to cardiac outpatient department should be done by such symptomatic patients and the lifesaving cardiovascular drugs should made available at primary center in case of emergency management.

\section{REFERENCES}

1. Sicree R, Shaw J, Zimmet P. The Global Burden: Diabetes and Impaired Glucose Tolerance. IDF Diabetes Atlas. $4^{\text {th }}$ ed. p. 1-105. Available from: http://www.idf.org/sites/default/files/The_Global_ Burden.pdf. [Last accessed on 2014 May 1].

2. Ahuja MM, Sivaji L, Garg VK, Mitroo P. Prevalence of diabetes in northern India (Delhi area). Horm Metab Res 1972;4:321-4.
3. Gupta OP, Joshi MH, Dave SK. Prevalence of diabetes in India. Adv Metab Disord 1978;9:147-65.

4. Chow CK, Raju PK, Raju R, Reddy KS, Cardona M, Celermajer DS, et al. The prevalence and management of diabetes in rural India. Diabetes Care 2006;29:1717-8.

5. Harris MI, Klein R, Welborn TA, Knuiman MW. Onset of NIDDM occurs at least 4-7 year before clinical diagnosis. Diabetes Care 1992;15:815-9.

6. Klein R, Knudtson MD, Lee KE, Gangnon R, Klein BE. The Wisconsin Epidemiologic Study of Diabetic Retinopathy XXIII: The twenty-five-year incidence of macular edema in persons with type 1 diabetes. Ophthalmology 2009;116:497-503.

7. Nouwen A, Winkley K, Twisk J, Lloyd CE, Peyrot M, Ismail K, et al. Type 2 diabetes mellitus as a risk factor for the onset of depression: $\mathrm{A}$ systematic review and meta-analysis. Diabetologia 2010;53:2480-6.

8. Available from: http://www. patienteducation.stanford.edu. [Last accessed on 2014 May 1].

9. Vaz NC, Ferreira A, Kulkarni M, Vaz FS, Pinto N. Prevalence of diabetic complications in rural Goa, India. Indian J Community Med 2011;36:283-6.

10. Ramachandran A, Snehalatha C, Satyavani K, Latha E, Sasikala R, Vijay V. Prevalence of vascular complications and their risk factors in type 2 diabetes. J Assoc Physicians India 1999;47:1152-6.

11. U.S. Department of Health and Human Services: National Diabetes Statistics, 2011. Available from: http://www.hhs.gov. [Last accessed on 2014 May 1].

How to cite this article: Bansode-Gokhe SS, Waghmare RB, Ratnendra RS. Diabetes mellitus: Implication in rural area of Thane district, India. J Soc Health Diabetes 2015;3:39-42.

Source of Support: Nil. Conflict of Interest: None declared. 